\title{
SOME REFLECTIONS OF A MEDICAL SOCIAL WORKER IN A SPINAL PARALYSIS UNIT
}

\author{
By MARJorie A. Thompson \\ Spinal Unit, Edenhall Hospital, Musselburgh, Scotland
}

Abstract. Seventeen years as the social worker to a spinal paralysis unit has clearly demonstrated the very great importance of treating the 'whole patient'.

Key words: Medical social worker; Spinal paralysis; Paraplegia.

SEVENTEEN YEARS as medical social worker in a spinal injuries unit has enabled me to look back and make some general observations about our achievements.

The goal of a spinal unit is the rehabilitation of the whole person; body, mind and spirit interacting to form a complete amalgam. Without this aim, the physical result of rehabilitation falls short, leaving the patient to hide from the world and himself in his wheelchair.

Sometimes the patient himself may say what he thinks you want to hear. For example, one tetraplegic man, with no residual sex function, said that he was swimming, helping with a club and other activities and had a settled home life. Then his very attractive wife asked to see me, suspecting him of telling 'white lies' and confirmed that he was going nowhere, doing nothing, and had become very jealous of her when she left the house, thus creating an added but understandable problem.

A second man had initially been considered for psychiatric referral, although this was not carried out as the general unease about his attitude towards his disability was dispelled as he cheered up prior to discharge. Five months later we heard that first his wife, then his teenage daughter, had attempted suicide. This man's total non-acceptance of his disability had literally made him impossible to live with.

These two cases, the one a frightened man with a crushed spirit; the other emotionally unable to accept reality, are extreme. One must, however, be ready to recognise and accept the failures, and to realise as Dr Parry did in the eighteenth century, that 'it is much more important to know what sort of person has the disease, than to know what sort of disease has the person'. (Ref. lecture by Cairns Aitken, Professor of Rehabilitation, Edinburgh University.)

Early predictions about the eventual outcome of rehabilitation are possible and the difficult patient in the unit, whom the staff despair of, will often do extremely well once he has discharged his uncertainty and aggression and can progress from there. On the other hand, cheerful smiling faces are suspect in new patients as they are often indicative of underlying confusion, fear and later problems. Just as the physical state of each patient is known, so we must be aware of the emotional state and the degree-or lack - of adjustment and acceptance.

What is considered 'perfect rehabilitation' is sometimes to be queried. The patient who has a very full life with a job of work, countless other activities and 'never a dull moment' gives one the impression of someone almost frenziedly searching for inner stillness and quiet. Total independence is good, but one step 
short of the more mature state of interdependence which marks the truly adult person.

In Scotland, the stability of marriage among paraplegics is very good. Cohabitees, however, even with long-standing relationships, tend to separate in time, but not immediately. Sometimes it takes a year or two for the problems to present, and awaiting settlement of a compensation claim may well prolong the uncertainty. This raises a question: are some wives under greater strain than they care to admit? Or are extra-marital relationships based on more physical bonds ? Which leads me to comment that I feel a little sour about the publications written about 'Sex for the Disabled' in which nothing is said about the percentage of those with no (physical) residual sex function. It is important to recognise and be aware of the areas where sucess has not been achieved.

Working in a small spinal paralysis unit has many compensations. It helps towards the 'whole person' approach, for not only do we know the patient well, but we know each other well. This makes for good all-round care, and a personal concern. We all see the patient when he comes back for review and remember his individual worries, be it his wife with multiple sclerosis, or his child on probation, or his compensation claim. Formal ward meetings and resettlement clinics are held and the full picture of the patient's physical, mental and emotional state is clearly seen by the time of the patient's discharge, in the more intimate family atmosphere of a small unit.

The well-settled paraplegic has, along with his physical treatment, been educated in the meaning of paraplegia in terms of daily living. He has mourned his lost powers and used his aggressive instincts to fight his way back to independence. He has a suitable house, suitably adapted. He has a job of work or a good interest or hobby. He has come to terms with the necessary adaptation or even suppression of his deep sexual instincts and has fitted back into his family life in his partially altered role.

This is a great deal to ask of any human being. We do have a duty at least to try to see that both the patient and his family find life worth while. A patient once said to his doctor, 'you prevent us from dying but you do not show us how to live'. This fearful indictment shows how negative the whole process can be if one does not take the whole person into account and carry rehabilitation through to the end.

\section{RÉSUMÉ}

Les expériences d'une assistante sociale qui a travaillé pendant dix-sept années dans un petit hôpital pour les paralysés spinales ont démontré conclusivement qu'il est d'une importance extrême que le malade soit traité comme personne totale et intégrale.

\section{ZUSAMMENFASSUNG}

Die Erfahrungen einter Sozial-Beraterin während einer Arbeit von siebzehn Jahren in einer Klinik für durch Rückgratverletzungen Gelähmte beweisen eindeutig, wie äusserst wichtig es ist, den Patienten als ganze, einheitliche Person zu behandeln. 